Удк 32

DOI 10.52468/2542-1514.2021.5(2).86-98

ОТВЕТСТВЕННОСТЬ ПРЕЗИДЕНТА И ПРОКУРАТУРЫ ЗА ЦЕЛОСТНОСТЬ И БЕЗОПАСНОСТЬ ГОСУДАРСТВА*

\author{
Н.А. Блохина, М.А. Власова \\ Тольяттинский государственный университет, г. Тольятти, Россия
}

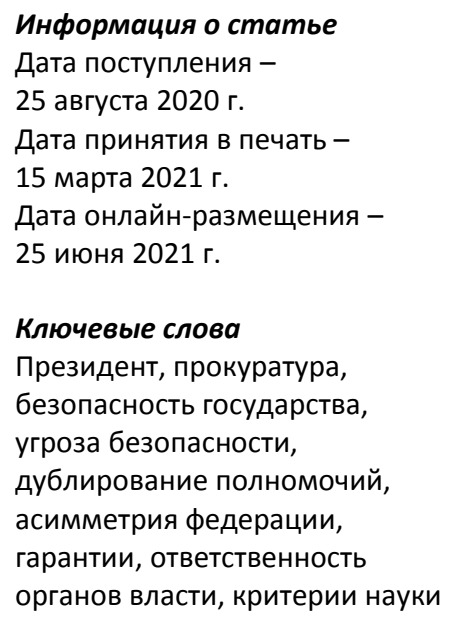

\begin{abstract}
Рассматривается эволюция гл. 7 Конституции РФ и освещается вопрос о том, кто и как спас прокуратуру России от попытки ее ликвидации осенью 1993 г. Отмечается, что в проекте Конституции РФ не было даже упоминания о прокуратуре, которую предполагалось заменить институтом полномочных представителей Президента в субъектах Российской Федерации. Раскрывается роль А.И. Казанника в сохранении российской прокуратуры. Освещаются угрозы целостности и единству России и гарантии их минимизации. Отмечается, что прокуратура выступает важнейшим органом в обеспечении безопасности государства и его целостности. Вносятся предложения о закреплении в Конституции РФ принципов функционирования прокуратуры, о расширении полномочий Генерального прокурора РФ и прокуроров субъектов федерации.
\end{abstract}

\title{
RESPONSIBILITY OF THE PRESIDENT AND THE PROSECUTOR'S OFFICE FOR THE INTEGRITY AND SECURITY OF THE STATE**
}

\author{
Natalia A. Blokhina, Maria A. Vlasova \\ Togliatti State University, Togliatti, Russia
}

\author{
Article info \\ Received - \\ 2020 August 25 \\ Accepted - \\ 2021 March 15 \\ Available online - \\ 2021 June 25
}

\section{Keywords}

President, prosecutor's office, national security, threat to security, duplication of authority, asymmetry of the federation, guarantees, responsibility of the authorities, criteria of science
The subject. The evolution of regulation of prosecutor's activity in Russian Constitution as well as the role of Prosecutor's Office in provision of national security and integrity are being considered.

The purpose of the article is to confirm or disprove hypothesis that the preservation of the Prosecutor's Office made it possible to prevent the destruction of the Russian Federation and protect the country's security from significant threats.

The methodology. The authors use a dialectical method as well as analysis and synthesis. An important role is given to formal legal interpretation of Russian Constitution and legal acts. The main results, scope of application. The question of who saved the Russian Prosecutor's Office from the attempt to liquidate it in the autumn of 1993 is being covered in detail. There was not even a mention of the Prosecutor's Office in the draft Constitution of the Russian Federation. The Prosecutor's Office was supposed to be replaced by the institution of authorized representatives of the President in the constituent entities of the Russian Federation. Chapter 7 of the Russian Constitution was called "Judicial Power" until 2014, and it lacked the word "prosecutor's office", which caused a lot of bewilderment in the sci

\footnotetext{
* Исследование выполнено при финансовой поддержке РФФИ и КН РА в рамках научного проекта № 20-511-05003.

** The reported study was funded by RFBR and SC RA, project number 20-511-05003.
} 
entific and educational literature and turned the content of Chapter 7 into a kind of mystery. The article reveals the role of Alexander I. Kazannik in preserving the Russian Prosecutor's Office. The authors of the article name the main threats to state security: duplication of the powers of the federal government and the lack of effective legal guarantees of their responsibility, asymmetry of Russian federalism. Asymmetry leads to uneven implementation of citizens' rights and freedoms and distrust of power. The criteria for assessing the scientific activities of universities established in 2013 also pose a threat to state security. Conclusions. President Vladimir Putin has preserved the integrity and sovereignty of Russia, enforced the principle of the supremacy of federal law and strengthens Russia's security with the help of the Prosecutor's Office. The authors propose measures to strengthen Russia's security: (1) introduce a competitive selection procedure for the post of Prosecutor General of the Russian Federation with the participation of civil society institutions, which would have the right to present candidates to the Federation Council; (2) adopt a federal law on the Administration of the President of the Russian Federation to avoid duplication of powers with the Russian Government and other authorities; (3) change the criteria for assessing the scientific activity of universities, established by the Ministry of Science of the Russian Federation.

\section{Посвящается памяти А.И. Казанника, профессора Омского государственного университета им. Ф.М. Достоевского, экс-Генерального прокурора РФ (октябрь 1993 - апрель 1994) в связи с предстоящим 80-летним юбилеем Учёного и Человека (26.07.1941-02.06.2019)}

\section{1. Введение: конец 1990-х - Россия на грани распада}

Развал Советского Союза в начале 1990-х годов

XX столетия стал геополитической катастрофой, что неоднократно признавал и подчёркивал впоследствии Владимир Путин. К концу 1990-х годов уже Россия была на грани распада к тому моменту, когда её возглавил В.В. Путин. Маргарет Тэтчер однажды назвала СССР «Верхней Вольтой с атомными ракетами», что было одним из идеологических ярлыков, с помощью которых Запад вёл холодную войну с СССР. Но Россия к концу 1990-х была ещё и обезоружена, причём, не только идеологически, но и в военном смысле. С. Степашин, будучи в 1999 г. премьерминистром, обогатил лексикон новым определением: «Россия - самая большая банановая республика без бананов». Но - самое главное! - в России к концу 1990-х разрушалось единое правовое пространство, без чего невозможны целостность, единство и национальная безопасность государства, равно как и обеспечение его суверенитета.

К этому времени в одной трети субъектов Российской Федерации законодательство противоречило Конституции РФ и федеральным законам, что, собственно, и есть начало распада страны. Иными словами, Россия вполне могла разделить участь СССР, распадаясь на «суверенные» республики, ко- торыми объявляли себя не только бывшие автономии СССР, но и некоторые области, руководство которых хотело иметь такие же полномочия и привилегии, как новоявленные президенты республик.

Норма, в соответствии с которой «Конституция Российской Федерации и федеральные законы имеют верховенство на всей территории Российской Федерации» (ч. 2 ст. 4 Конституции РФ), нарушалась безнаказанно, и даже прокуроры, зависимые больше от региональных элит, нежели от Президента РФ, были бессильны. Дело в том, что действовавшая на тот момент конституционная норма и реформированная лишь в 2014 году, гласила: «Прокуроры субъектов Российской Федерации назначаются Генеральным прокурором Российской Федерации по согласованию с её субъектом» (ч. 3 ст. 129 Конституции РФ в ред. до 2014 г.). Таким образом, фактически «согласованные» прокуроры регионов если и не были ставленниками глав регионов (а зачастую, именно последние подбирали прокурора из местных кадров), то во многом зависели от них, становились «ручными» прокурорами. Всё это приводило к тому, что в регионах формировалась собственная «региональная законность».

Кроме того, в законодательстве отсутствовали процессуальные нормы, позволявшие прокурорам вносить представления в суд о признании недей- 
ствующими и не подлежащими применению региональных нормативных актов, противоречащих законам Российской Федерации,

Что уж тут говорить об отдельных гражданах и депутатах, пытавшихся обжаловать «незаконные» региональные законы! Так, депутат Н. Боброва почти год судилась с Самарской Губернской Думой и Губернатором Самарской области, пытаясь признать недействующим и не подлежащим применению Закон Самарской области «Об ипотеке земель сельскохозяйственного назначения», напрямую противоречащий федеральному законодательству. Все суды вплоть до Верховного Суда отделывались отписками, ссылаясь на отсутствие норм ГПК, которые бы позволяли обжаловать и отменять законы регионов, противоречившие федеральным законам. Почти детективная эпопея неравной борьбы за конституционный принцип верховенства федеральных законов описана ещё до того [1], как Президент В.В. Путин указал на прямые обязанности прокуроров субъектов Российской Федерации. Тут же и прокурор Самарской области, бездействовавший до этого, опротестовал вышеупомянутый областной закон.

2. Эпоха суверенизации закончилась. Роль Президента В. Путина В сохранении целостности российского государства

В.В. Путин стал мощной преградой на пути раздиравших страну центробежных сил, для чего использовал "спящую» до него норму Конституции, в соответствии с которой Президент РФ «принимает меры по охране суверенитета Российской Федерации, её независимости и государственной целостности...» (ч. 2 ст. 80 Конституции РФ).

Самарский регион может гордиться тем, что политика приведения законодательства субъектов Российской Федерации в соответствие с федеральным законодательством была озвучена на самарской земле. В конце августа 2000 года произошло никем особенно не замеченное, но очень важное политическое событие: во время рабочей поездки в Тольятти Владимир Путин поставил жирную точку в истории с ельцинской эпохой суверенитетов.

«Самарская газета» отмечала: «Приснопамятный лозунг Ельцина «Берите суверенитета, сколько проглотите!», брошенный им из здания Верховного Совета нынешней лишь «ассоциированной с Российской Федерацией Республикой Татарстан», его пре-

\footnotetext{
1 Бондаренко А. Пришёл конец эпохе суверенитетов // Самарская газета. 05.09.2000. С. 2. 2 Там же.
}

емник заменил лозунгом «сильного и эффективного государства» и призывом беречь и укреплять «целостность правового пространства России». (...) на торжественный обряд своеобразного аутодафе суверенитетов он пригласил главных защитников национально-боярской суверенности - президентов Татарстана и Башкортостана Минтимера Шаймиева и Муртазу Рахимова. Время, место и состав участников Президентом были выбраны не случайно: Самарская область - сосед Башкирии и Татарстана, (...) добивается равенства субъектов Федерации перед государственным бюджетом ${ }^{1}$.

Происходило данное совещание глав регионов Поволжья в санатории «Волжский утёс» (строился в советские времена для членов ЦК КПСС и сотрудников его аппарата). В.В. Путин говорил два часа о правовом «бардаке» в регионах жёстко, а в конце дипломатично подчеркнул: «Должен сказать, что из присутствующих здесь, да и всех других руководителей регионов, никого нет, кто бы отстаивал сепаратистские принципы. Все заинтересованы, чтобы государство у нас было единым и эффективным. К сожалению, единого правового поля в стране до сих пор нет. И речь идёт не только о национальных республиках. И в уставах областей, и в конституциях республик можно найти всё, что угодно: и суверенитет, и международную правосубъектность. Можно найти всё - от гвоздей до бриллиантов. Нет только упоминания о том, что это субъект Российской Федерации. Подавляющее большинство населения страны - и я это ответственно заявляю, - не представляют, в каком государстве мы живём. И вот эта мина замедленного действия должна быть изъята и уничтожена» ${ }^{2}$.

В.В. Путин «уничтожил эту мину», а также укрепил президентскую вертикаль созданием института федеральных округов и полномочных представителей Президента в них ${ }^{3}$.

3. Институт полномочных представителей Президента РФ как несостоявшаяся альтернатива прокуратуры

Впрочем, полномочия представителей Президента РФ в федеральных округах пересекаются с компетенцией его полномочных представителей в субъектах Федерации. Собственно, сам институт полномочных представителей Президента в субъектах Российской Федерации (п. «к» ст. 83 Конституции

3 Указ Президента РФ от 13 мая 2000 г. № 849 // С3 РФ. 2000. № 20. Ст. 2112. 
РФ) появился в тексте Конституции потому, что в окончательном проекте, подготовленном к печати (проект опубликован 10.11.1993), вовсе не было прокуратуры как органа власти, и только Генеральный прокурор А.И. Казанник, добившийся приёма у Б.Н. Ельцина 9 ноября 1993 года, сумел убедить президента в том, что прокуратуру уничтожать нельзя, и попросил включить в проект хотя бы один из предложенных им вариантов статьи о прокуратуре, в результате чего короткий вариант на скорую руку был вставлен в главу “Судебная власть ${ }^{4}$. При этом те, кто вносили статью 129 в проект главы 7 Конституции, не догадались изменить название главы, включив в него слово «прокуратура».

«Ошибка» была исправлена лишь в 2014 году, когда гл. 7 Конституции РФ получила название «Судебная власть и прокуратура» с одновременным усилением полномочий Президента РФ, в том числе в отношении назначения и освобождении от должности прокуроров субъектов Российской Федерации, что ранее было в компетенции Генерального прокурора РФ (в скобках заметим, что это далеко не единственное юридическое усиление полномочий Президента РФ: новых полномочий Президента, появившихся в текущем законодательстве, насчитывается уже около пятисот).

\section{4. Кто спас прокуратуру России от задуманной} ликвидации?

В проекте Конституции, который направили в набор 9 ноября 1993 года, не было даже такого слова - «прокуратура», ибо авторы новой конституции предполагали заменить её институтом полномочных представителей Президента в субъектах Российской Федерации. К ним же, полномочным представителям, должен был перейти и кадровый аппарат прокуратуры, но лишь в его «лояльной» части.

На наш взгляд, институт полномочных представителей Президента в субъектах Федерации, ещё имевший какой-то смысл при Ельцине, в условиях прямых выборов глав регионов, когда на выборах побеждали независимые от Президента РФ ставленники финансово-промышленных группировок, лидеры национальных кланов и даже, что было крайне редко, народные кумиры (напр., Михаил Евдокимов), то после отмены прямых выборов глав регионов институт полномочных представителей Президента РФ в субъектах Федерации становится декоративным и дублирующим рудиментом. Кстати ска-

\footnotetext{
${ }^{4}$ Казанник А. «Отдал свой мандат Ельцину из чувства спра-
} ведливости и не жалею об этом». Интервью корр. ТАСС зать, на данное обстоятельство не слишком повлиял возврат прямых выборов губернаторов, тем более что муниципальный фильтр превратил эти выборы в плебисцит по одобрению/неодобрению президентских кандидатур.

Кто же спас российскую прокуратуру от задуманной ликвидации? Н.А. Боброва на основе личной беседы с профессором Омского государственного университета А.И. Казанником в апреле 2018 года (она была официальным оппонентом на защите кандидатской диссертации С.В. Иванова, аспиранта А.И. Казанника), а также на основе изучения опубликованного интервью А.И. Казанника приходит к выводу, согласно которому «спас прокуратуру один человек - Казанник Алексей Иванович. Будучи на момент разработки проекта конституции Генеральным прокурором РФ, А.И. Казанник, узнав, что в проекте конституции отсутствует статья о прокуратуре, добился приёма у Б.Н. Ельцина за считанные часы до публикации проекта и сумел убедить его в том, что прокуратуру ликвидировать нельзя, ибо в таком случае он останется в истории правителем, уничтожившим прокуратуру, в то время как её создал Пётр I, с которым народ сравнивает Ельцина. Эта невинная лесть, как говорится, ложь во спасение, позволила А.И. Казаннику спасти для России прокуратуру!» [2, c. 29].

По мнению Н.А. Бобровой, «прокуроры России должны были (...) поставить прижизненный памятник Алексею Ивановичу. Ведь благодаря ему прокуроры имеют работу. Благодаря этому Человеку именно так, а не иначе, сложилась вся система правоохранительных органов России» [2, с. 30].

В ту же ночь в уже свёрстанный проект конституции был вставлен краткий вариант статьи 129 о прокуратуре (А.И. Казанник положил перед Ельциным два варианта - развёрнутый и краткий). Впоследствии, по словам А.И. Казанника, он грустно улыбался, когда встречал очередную публикацию с размышлениями и вопросами о том, каким образом статья о прокуратуре попала в главу «Судебная власть», ведь прокуратура - не часть судебной власти.

В качестве примера приведём цитаты из учебника по конституционному праву С.А. Авакьяна: «Существование прокуратуры РФ предусмотрено Конституцией РФ. В ее гл. 7 «Судебная власть» имеется лишь одна статья (ст. 129), посвященная прокуратуре, в которой весьма туманно говорится о статусе

А. Петрову // Информагентство. 9.06.2016. URL: http:// tass. ru/opinions/interviews/3347868 (дата обращения 18.05.2020) 
и назначении прокуратуры. С одной стороны, вызывает множество вопросов помещение статьи в гл.7 получается, что прокуратура является частью судебной власти. (...) у прокуратуры нет функции вынесения судебных решений (...) прокуратура в большей мере, чем другие субъекты права, взаимодействует с судом. И все-таки это не делает ее частью судебной власти, в силу чего позволителен вывод о прокуратуре как о самостоятельной ветви государственной власти в Российской Федерации» [3, с. 731]. Приведём воспоминания о беседе А.И. Казанника и Б.Н. Ельцина, состоявшейся 9 ноября 1993 года в 22.00, чтобы понять и ощутить, на каком волоске висела вся прокуратура в ночь перед опубликованием проекта Конституции. Казалось, уже все аргументы были исчерпаны, и Президент вбил заключительный гвоздь словами: «А зачем вообще прокуратура нужна? Это пережитки тоталитарного социализма. Да и проект уже свёрстан. К тому же у нас теперь всё решается коллегиально».

Смысл этих слов был безнадёжным. А.И. Казанник вспоминает: «Страшно переживая за прокуратуру, говорю: “Борис Николаевич, прокуратуру учредил Пётр Первый”. - “Я это знаю”. - “А в народе вас сравнивают с ним. Говорят, что вы реформатор, продолжатель его дела. Как-то будет непонятно: Пётр Первый учредил, а такой же деятель (...) упразднил". Ельцин задумался и спрашивает: "Что вы говорите? Неужели так и рассуждают?” - “Да, Борис Николаевич, все так и говорят!” - “Надо же! Я этого не знал. Ну, оставьте на всякий случай”. Второй вариант статьи я оставил и к трём ночи, когда экспедиция привозит почту, поехал в генпрокуратуру. Приносят газету с опубликованным проектом Конституции. Смотрю, а там моя статья стоит в разделе "Судебная власть". То есть ни к селу, ни к городу. Но самое главное, что прокуратура сохранена» ${ }^{5}$.

Да, действительно, была сохранена прокуратура как единственный эффективный институт государственной власти, государственный инструмент, который позволил В.В. Путину в 2000 году начать и блестяще осуществить политику восстановления единой федеральной законности, прекратить политику дробления законности на «калужскую и казанскую», «башкирскую и алтайскую».

\footnotetext{
${ }^{5}$ Казанник А. «Отдал свой мандат...»

${ }^{6}$ Там же.

7 Новости политики. О съезде законодателей России // Обозрение. 05.07.1999. № 28. С. 1-2.
}

Именно прокуратура по поручению В.В. Путина быстро привела в соответствие с Конституцией и федеральным законодательством уставы и законы субъектов РФ. «Беспрецедентный шаг Главы России остановил центробежные процессы» ${ }^{6}$. В самом деле, ситуация к концу 90-х была настолько тревожной, а центробежные силы настолько сильны, что под угрозой была уже целостность России, которой грозила участь Советского Союза, ибо разгул разрушения единого правового пространства России, казалось, был необратим.

Причём некоторые региональные лидеры уже подводили идеологическую базу под свои нормативные акты, противоречащие федеральным законам. Например, Губернатор Самарской области К.А. Титов, выступая 4.07.1999 г. в Самаре на съезде Союза законодателей России, заявил, что «из-за сложившейся ситуации органы власти области просто вынуждены нарушать закон» ${ }^{7}$. И далее: «Нередко центр откровенно провоцирует местное руководство на нарушения законодательства (...). Субъекты Федерации вынуждены принимать законы, противоречащие федеральным законам ${ }^{8}$. Вот ведь как: «Вынуждены!». Но К.А. Титов был не единственным губернатором, думавшим так же. Они идеологически оправдывали принятие своих законов, противоречащих федеральным законам.

К концу 1990-х единое правовое пространство России было существенно разрушено. К тому же через Конституционный Суд РФ сепаратисты пролоббировали Постановление от 16 июня 1996 года, согласно которому суды общей юрисдикции не могут рассматривать дела о противоречии региональных нормативных актов федеральным законам в силу отсутствия процедуры рассмотрения этих дел. Осуществлена легализация правового беспредела регионов [1].

Народ уже испытал одну геополитическую катастрофу, утратив СССР, но надвигалась новая, и спасать надо было уже Россию, что и сделал В.В. Путин, начав политику приведения региональных нормативных актов в соответствие с федеральным законодательством.

Хотелось бы привести цитату из книги Н.А. Бобровой: «Перед зданием Генеральной прокуратуры надо бы поставить три памятника: Петру Первому

8 Титов К.А. Регионы - вперёд! // Волжская коммуна. 06.07.1999. С. 1. 
как создателю "государева ока", Алексею Казаннику как человеку, благодаря которому не уничтожена российская прокуратура, и Владимиру Путину как Президенту, напомнившему региональным царькам и прокурорам о принципе верховенства федерального законодательства. Президент с помощью прокуратуры восстановил единое правовое пространство России и тем самым сохранил Россию» [2, с. 32].

2 июня 2019 года А.И. Казанник ушел из жизни. Книга Н.А. Бобровой вышла 7 июня. Её увидели лишь вдова и сыновья Алексея Ивановича.

Пожалуй, в истории России никогда не было и больше не будет Генерального прокурора, который был в этой должности менее полугода и который успел сделать столь много. Между прочим, после спасения прокуратуры, он освободил из Лефортово членов ГКЧП, а после этого добровольно подал рапорт об отставке (при этом так и не вселился в предоставленную ему московскую квартиру и вернулся в Омский государственный университет).

\section{5. Эволюция главы 7 Конституции РФ в части} статуса прокуратуры и укрепления влияния на неё президентской власти

Глава 7 приобрела своё нынешнее название «Судебная власть и прокуратура» в результате поправок 2014 года, но вряд ли инициаторы поправок руководствовались необходимостью привести название главы в соответствие с её содержанием, о чём конституционалисты написали немало страниц. Мнение ученых волновало власть менее всего, и глава ещё долгое время носила бы неадекватное её содержанию название, если бы не понадобилось очередное укрепление вертикали президентской власти.

Часть 3 ст. 129 Конституции РФ гласила: «Прокуроры субъектов Российской Федерации назначаются Генеральным прокурором Российской Федерации по согласованию с её субъектами», а часть 4 ст. 129 гласила: «Иные прокуроры назначаются прокурором Российской Федерации».

В результате реформы-2014 заместители Генерального прокурора РФ стали назначаться на должность и освобождаться от должности не самим Генеральным прокурором РФ, а в таком же порядке, в каком назначается на должность и освобождается от должности Генпрокурор, а именно: заместители Генерального прокурора РФ назначаются на долж- ность и освобождаются от должности Советом Федерации по представлению Президента РФ.

В результате реформы-2020 к ведению Совета Федерации отнесено проведение консультаций по предложенным Президентом Российской Федерации кандидатурам на должность Генерального прокурора Российской Федерации, заместителей Генерального прокурора РФ, прокуроров субъектов Российской Федерации, прокуроров военных и других специализированных прокуратур, приравненных к прокурорам субъектов Российской Федерации (п. «з» ст. 102 Конституции РФ). Назначает же всех этих прокуроров Президент РФ.

Такова эволюция названия главы 7 и содержания ст. 129 Конституции РФ, что свидетельствует о поэтапном укреплении централизации прокуратуры на основе "президентского стержня», президентской власти, позволяющей с помощью централизованной прокуратуры укреплять целостность, единство и безопасность России.

\section{6. Угрозы целостности и единству России и га-}

\section{рантии их минимизации}

Гарантиям единства и территориальной целостности Российской Федерации посвятил свою диссертацию С.В. Иванов, аспирант А.И. Казанника. Он, в частности, обратил внимание на проблему дублирования государственных функций и привёл конкретные примеры того, как конституционная конкуренция между высшими органами государственной власти способна породить состояние двоевластия сильнейшую угрозу единству и территориальной целостности страны [4, с. 41, 43].

Кстати, в конституционной реформе-2020 усмотрел угрозу стабильности России С.М. Шахрай, полагая, что поправки провоцируют «семибоярщину». По его мнению, в результате реформы возникает несколько центров конституционного влияния, которые в будущем станут площадкой для открытой политической борьбы экономических кланов, то есть закладывается мина под стабильность России ${ }^{9}$. Он, в частности, увидел такую "мину» и в Конституционном Суде РФ, и в обеих палатах Федерального Собрания, с чем вряд ли можно согласиться, ибо умаление Конституционного Суда доведено поправками до последней черты, а формирование Совета Федерации в огромной степени зависит от Президента. Что же касается Государственной Думы, полномочия ко-

\footnotetext{
9 «Семивластие». Интервью Андрея Угланова с Сергеем Шахраем // Аргументы недели. 04-10.03.2020. С. 1, 3.
} 
торой якобы существенно возрастают при формировании Правительства, то это, на наш взгляд, только видимость.

Серьёзную проблему представляет только дублирование полномочий Администрации Президента РФ и Правительства РФ, Президента РФ и Государственного Совета РФ, что в будущем действительно порождает риск возникновения ситуации двоевластия, несовместимого с единством государственной власти России и угрожающего её территориальной целостности.

Ни в коем случае нельзя допустить «регионализации» прокуратуры с переподчинением прокуроров органам государственной власти субъектов РФ (к сожалению, такая тенденция в разных регионах и в разной степени всё-таки наблюдается). В регионах распространены, например, такие «мелочи», как награждение ко Дню юриста и в связи с разными другими событиями наградами субъектов Российской Федерации прокурорских работников и судей.

Считаем, что прокуроры и судьи могут награждаться только федеральными наградами, поскольку прокуроры служат только Конституции РФ и федеральному законодательству.

Несомненно, следует считать пробелом, что ни в Конституции РФ, ни в ФКЗ «О Конституционном Суде РФ» не содержится упоминания о Генеральном прокуроре как субъекте обращения в Конституционный Суд РФ по вопросу нарушения конституционных прав и свобод граждан РФ. Пробелом является и то, что Генеральному прокурору РФ не принадлежит право законодательной инициативы по вопросам ведения прокуратуры. Понимая, почему так произошло (по замыслу творцов Конституции прокуратура вообще должна была исчезнуть), мы тем более настаиваем на том, что эта историческая ошибка должна быть исправлена.

Статью 10 Конституции РФ следовало бы сформулировать так, чтобы из неё исходило единство государственной власти в её разделении не на «подвласти» как части, а на «ветви как функции». Однако Конституция РФ несет в себе отпечаток предшествующего её принятию президентского указного права.

С.В. Иванов отрицательно оценивает поправки федерального законодателя от 28.06.2014 г., позволяющие совмещать полномочия депутата регионального парламента и Совета Федерации (во вто-

10 О тайне Фургала и Приморье - консервах для Китая. Интервью В.А. Штырова гл. редактору «АН» А. Угланову // Аргументы недели, 29.07-04.08.2020. - С. 1, 3, 8-9. ром абзаце ст. 9 Раздела второго «Заключительные и переходные положения» Конституции РФ члены Совета Федерации именуются депутатами Совета Федерации, в соответствии с реформой-2020 они теперь будут именоваться сенаторами). Поправки были приняты с целью исключения необходимости проведения дополнительных выборов в результате наделения полномочиями члена Совета Федерации депутата законодательного органа, избранного по одномандатному избирательному органу. По его мнению, «организационное присутствие какой-либо из палат Федерального Собрания РФ в составе законодательного органа субъекта РФ не способствует самостоятельности последнего» [4, с. 176]. Однако на эту проблему следует посмотреть и с другой стороны, особенно зная, как она вообще возникла (когда появилась норма о назначении члена Совета Федерации только из числа лиц, когда-либо избранных в представительные органы власти любого уровня). Это «организационное присутствие» не столько ослабляет регион, сколько укрепляет его лоббирующие возможности и организационные связи с Центром. Иные сенаторы редко появляются в регионе, который они представляют, а тут сама необходимость заставляет их регулярно бывать в регионе и проникаться его интересами на заседаниях регионального заксобрания, депутатских приёмах и встречах с избирателями и т. д.

Значительно большую угрозу государственной безопасности асимметрия Российской Федерации, фактически не имеющая пределов и достигающая весьма опасных величин по всем параметрам [5-7], в том числе бюджетным [8]. По мнению лучшего специалиста по Дальнему Востоку, экс-президента Якутии, советника Совета Федерации по Дальнему Востоку В.А. Штырова, митинги протеста, прокатившиеся в Хабаровском крае в связи с отставкой губернатора края Сергея Фургала были не столько митингами в его защиту, сколько обозначили точку кипения недовольства дальневосточников политикой государства в отношении дальнего Востока и Сибири в целом ${ }^{10}$.

Особенное внимание в плане государственной безопасности ученые уделили конституционно-правовой ответственности субъектов Российской Федерации [9-11]. Эту ответственность именуют также федеративной ответственностью или ответственностью в федеративных отношениях [12-14]. Ученые 
уделили также внимание конституционной ответственности органов государственной власти субъектов Федерации [15; 16] и их высших должностных лиц $[17 ; 18]$, равно как соответствующим деликтам в названных сферах.

Ещё при советской власти признавалась и исследовалась конституционно-правовая ответственность органов государственной власти, равно как и сейчас исследуется ответственность органов государственной власти Российской Федерации [19-21], в том числе Президента РФ [22] и государства в целом.

Государство может быть субъектом юридической ответственность либо в международно-правовом аспекте, либо в широком конституционном аспекте, если имеется в виду ответственность государства перед народом, перед личностью, а также в собственно-юридическом аспекте, если имеется в виду ответственность государства за причинение вреда физическим и юридическим лицам по вине государственных органов и должностных лиц. Поэтому чаще всего, за некоторыми исключениями [23], ученые исследуют не конституционную ответственность государства перед личностью и народом, имеющую философский и даже сакральный смысл [24, с. 37], а ответственность отдельных органов государственной власти и должностных лиц. Но в любом случае такая ответственность преломляется через призму государственной безопасности [25], даже если речь идёт о необходимости укрепления местного самоуправления [26] или даже проблем, возникающих в сфере реализации прав человека и гражданина [27], ибо количество граждан. не имеющих реальной возможности для реализации своих прав и свобод, является чрезвычайно высоким и предельно критически в аспекте именно государственной безопасности, доверия населения к власти.

Всегда есть политики и учёные, которые заявляют о равновеликой, «солидарной» ответственности гражданского общества и государства в обеспечении законности, реализации прав человека и гражданина, однако перекладывание вины и «размазывание» ответственности государственных органов и должностных лиц на всё общество согласно пресловутой фразе о том, что общество имеет то правительство, которое заслуживает, есть удобная позиция для лиц, отвечающих за состояние законности на конкретном участке властвования и управления.

Р.Б. Булатов и С.Ю. Андрейцо, правильно ставя вопрос о необходимости генеральной концепции конституционного развития российского общества, пишут, что «знаковым элементом генеральной концепции должна быть государственная политика в сфере конституционных преобразований, суть которой - обеспечить солидарную деятельность и ответственность общества за качественную сторону Основного Закона» [28, с. 69]. На наш взгляд, это тот случай, когда ответственность “солидарно» перекладывается с больной головы на здоровую, хотя, конечно, современное общество здоровым назвать проблематично, и не только российское. И всё-таки общество властными полномочиями не обладает и в силу этого не может нести равновеликую и «солидарную» с государством ответственность за состояние законности. Но моральную ответственность, ответственность перед Богом и своей совестью несёт, разумеется, каждый российский гражданин.

7. Разрушительное влияние современных критериев оценки научной деятельности российских вузов на интересы и суверенитет России

О вредоносности критериев оценки научной деятельности вузов, установленных Приложением к Приказу Министерства образования и науки РФ от 10.12.2013 № 1324, писали и выступали на научных конференциях многие ученые [29; 30]. В Данном Приложении закреплён приоритет публикаций в зарубежных журналах и изданиях, индексируемых в базах цитирования Scopus и Web of Science, причём, вне зависимости от специализации, что особенно больно ударило по гуманитарным, в том числе юридическим, наукам. На момент появления данных одиозных критериев в России не было ни одного юридического журнала, индексируемого в этих базах, кстати, администрируемым частными фирмами, зарабатывающими на этом деньги. На данный момент лишь семь российских юридических журналов отнесены к этим базам цитирования, но это капля в море. К чему это приводит? Статья российского ученого в малазийском, филиппинском или испанском журнале ценится выше, чем его же статья в таких великолепных журналах, как «Конституционное и муниципальное право», «Государство и право», «Правоприменение» и многие другие отечественные журналы, хотя их прочтёт множество российских специалистов, аспирантов и студентов, а в малазийском и филиппинском журнале, скорее всего, единицы.

Вузы вынуждены принимать локальные нормативные акты в соответствии с установками профильного Министерства, предоставляющими более высокие баллы за статьи в Scopus и Web of Science. Соответственно, каждый вуз устанавливает свои нормы 
оплаты трудозатрат преподавателя за статьи в Scopus $и$ Web of Science. При этом никакие иные статьи и даже солидные монографии в материальном смысле не поощряются.

Помимо более высокой оценки статей в Scopus и Web of Science, вузам дают дополнительные баллы за наличие в составе профессорско-преподавательского состава (ППС) вуза, и даже его руководства, зарубежных ученых и специалистов. Последнее обстоятельство напрямую дискриминирует российских ученых и, более того, ущемляет суверенитет России. В некоторых вузах массово стали оформлять зарубежных ученых в качестве совместителей. Зачастую фактически они только «числятся» и получают заработную плату, а их учебную нагрузку выполняет преподаватель-россиянин.

Кроме того, названный Приказ отдаёт преимущества в финансировании тем вузам, которые приучают сотрудников зарабатывать деньги для вуза. Устанавливаются нормы НИОКР для преподавателей в 50-100-200 тысяч рублей в год. Преподаватели в обязательном порядке должны либо выигрывать гранты на требуемую сумму, либо заключать хозяйственные и консультативные договоры с юридическими лицами, где третье стороной (выгодоприобретателем) является вуз. В случае, если преподаватель не выполняет норм НИОКР, его лишают премии, а могут и не продлить контракт с вузом на новый срок.

Даже в США на разных кафедрах существуют разные критерии оценки научных заслуг ППС, поскольку юристы-теоретики и историки не могут быть приравнены к цивилистам и криминалистам по возможности, например, заключения договоров с различными фирмами по консультированию, разработке нормативных правовых актов и так далее.

Наряду с неоправданным нивелированием «физиков» и «лириков» в аспекте оценки их научных достижений, происходит другой, казалось бы, противоположный процесс, но одинаково чреватый угрозами национальной безопасности. Речь идёт о предоставлении определённому перечню вузов права не только самим присуждать учёные степени, но и разработки и утверждения «перечня научных областей и специальностей». К каким вольностям и нарушениям законодательства это приводит, С.В. Нарутто показала на примере НИУ «Высшая

11 Приказ НИУ ВШЭ в ред. от 16.04.2018 г. № 6.18.1-01/ 1604/07 «Об утверждении Положения о присуждении учё- школа экономики», Приказ которого ${ }^{11}$ нарушает действующее законодательство [31].

Возвращаясь к Приказу Минобрнауки об оценке научных достижений вузов, следует подчеркнуть, что он фактически нивелировал степени кандидата и доктора наук (вуз оценивается по общему количеству степеней без градации на докторскую и кандидатскую), что является явным ущемлением интересов профессуры, особенно профессуры советской школы, что также является дискриминирующим обстоятельством, но уже по возрасту и заслугам. Приказ отдаёт предпочтение молодым ученым, так как. дополнительные баллы вуз получает не за научные школы и маститых профессоров, а за профессоров моложе 35-40 лет. В физико-математических и других естественных дисциплинах молодых докторов и профессоров больше. Однако в гуманитарных дисциплинах - иная картина. Чтобы вырастить профессора, вузу требуется 15-25 лет. Каждый профессор - это имя, достижение вуза. В других странах статус профессора давно поднят на должную высоту. В свое время профессор А.И. Казанник был на стажировке в Германии и поразился тому, что к каждому профессору прикрепляют до четырех оплачиваемых помощников. В Германии шкала оплаты труда ППС зависит от оплаты труда профессора, а в паспорте профессора проставляется слово «professor». И обращаться к такому гражданину принято со словом «профессор».

Описанные проблемы в системе регулирования подготовки кадров объективно требуют внимания со стороны органов прокуратуры.

\section{8. Выводы и рекомендации}

1) В Конституции РФ должны быть перечислены такие принципы работы прокуратуры РФ, как централизация, независимость от каких бы то ни было органов власти и общественных объединений, надзор за соблюдением и исполнением федеральных законов как исключительная функция прокуратуры.

2) Необходимо пресекать любые симптомы «регионализации» прокуратуры с переподчинением прокуроров органам государственной власти регионов.

3) Необходимо запретить награждать прокуроров и судей региональными и муниципальными наградами.

ных степеней в «Национальном исследовательском университете «Высшая школа экономики». URL: https:// www.hse.ru/doks/218589582.html. 
4) Требуется предоставить Генеральному прокурору РФ право законодательной инициативы в Государственной Думе РФ.

5) Следует предоставить Генеральному прокурору РФ и прокурорам субъектов Федерации право обращения в Конституционный Суд РФ в интересах граждан и их коллективов.

6) Необходимо ввести процедуру конкурсного отбора на должность Генерального прокурора РФ с участием институтов гражданского общества, которые имели бы право представлять кандидатов Совету Федерации (данное предложение уже высказывалось [8, с. 183]).

7) Каждому российскому прокурору, от Генерального до самого рядового, следует знать историю попытки ликвидации прокуратуры России осенью 1993 года и имя Генерального прокурора РФ А.И. Казанника, сумевшего спасти прокуратуру.

8) Каждому российскому прокурору следует прочесть интервью А.И. Казанника корреспонденту TACC [3].

9) Считаем целесообразным просить руководство Омского государственного университета напра- вить обращение Генеральному прокурору РФ и Президенту РФ об установке памятника А.И. Казаннику (авторы данной статьи тоже намерены это сделать вместе с профессором Н.А. Бобровой и другими представителями научной общественности).

10) Насущно необходимо принять федеральный закон «Об Администрации Президента Российской Федерации» во избежание дублирования полномочий с Правительством РФ и другими органами власти.

11) Следует изучить все предложения по гарантированию единства, целостности и безопасности России с целью закрепления самых ценных из них в законодательстве и недопущения ослабления единства и безопасности России.

12) Критерии оценки научной деятельности вузов, установленные Минобрнауки РФ Приказом от 10.12.2013 года № 1324, должны быть изменены как противоречащие государственным интересам России и её суверенитету.

13) Необходимо отменить право вузов, получивших право присуждать ученые степени, самим разрабатывать и утверждать перечень научных областей и специальностей.

\section{СПИСОК ЛИТЕРАТУРЫ}

1. Боброва Н.А. «Война законов», или «О недопустимости ослабления гарантий верховенства федерального законодательства» / Н.А. Боброва // Закон и право. - 2000. - № 2. - С. 28-33.

2. Боброва Н.А. Дума о Думе: дневники и мемуары депутата четырёх созывов. К 25-летию Самарской Губернской Думы / Н.А. Боброва. - Самара : Самарский центр РАН, 2019. - 195 с.

3. Авакьян С.А. Конституционное право России : учебный курс : в 2 т. / С.А. Авакьян. - 4-е изд., перераб. и доп. - М. : Норма : ИНФРА-М., 2010. - Т. 2. - 928 с.

4. Иванов С.В. Конституционно-правовые гарантии государственного единства и территориальной целостности Российской Федерации : дис. ... канд. юрид. наук / С.В. Иванов. - Омск, 2018. - 244 с.

5. Казанник А.И. Конституционно-правовые гарантии единства и территориальной целостности современных федеративных государств (сравнительный анализ) / А.И. Казанник // Вестник Омского университета. Серия «Право». - 2015. - № 4 (45). - С. 35-46.

6. Иванов С.В. Конституционно-правовое обеспечение государственного единства и территориальной целостности современной России (социально-экономический аспект) / С.В. Иванов // Правоприменение. 2019. - T. 3. № 1. - C. 44-54. - DOI: 10.24147/2542-1514.2019.3(1).44-54.

7. Малый А.Ф. О равноправии субъектов Российской Федерации и критериях его проявления / А.Ф. Малый // Конституционное и муниципальное право. - 2019. - № 7. - С. 51-54.

8. Костюков А.Н. Правовые аспекты обеспечения налоговой безопасности государства / А.Н. Костюков, К.В. Маслов // Вестник Омского университета. Серия «Право». - 2015. - № 4 (45). - С. 117-121.

9. Виноградов В.А. О конституционной деликтности законодательства субъектов Российской Федерации / В.А. Виноградов // Конституционное законодательство субъектов РФ / под ред. С.А. Авакьяна. - М. : МГУ, 1999. - С. 33-37.

10. Лебедев В.А. Теоретические основы конституционно-правовой ответственности субъектов Российской Федерации / В.А. Лебедев // Вестник Челябинского государственного ун-та. Серия 9. Право. - 2001. № 1(1). - С. 45-51. 
11. Нарутто С.В. Проблемы юридической ответственности субъекта Федерации / С.В. Нарутто // Правоведение. - 1998. - № 4. - С. 17-22.

12. Агапов А.С. Конституционно-правовая ответственность в федеративных отношениях : автореф. дис. ... канд. юрид. наук / А.С. Агапов. - М., 2008. - 24 с.

13. Барциц И.Н. Федеративная ответственность. Конституционно-правовые аспекты / И.Н. Барциц. - М. : Изд. Научно-образ. лит. РЭА, 1999. - 197 с.

14. Заметина Т.В. Конституционно-правовые основы федеративной ответственности / Т.В. Заметина // Ленинградский юридический журнал. 2012. № 2(28). - С. 4-9.

15. Безруков А.В. Модернизация мер конституционной ответственности органов государственной власти субъектов РФ в условиях федеративных преобразований / А.В. Безруков // Государственная власть и местное самоуправление. - 2010. - № 5. - С. 55-59.

16. Кондрашёв А.А. Конституционно-правовая ответственность субъектов федерации: вопросы теории и законодательного регулирования в Российской Федерации / А.А. Кондрашёв. - Красноярск : Сибирский юр. ин-т МВД РФ, 1999. - 111 с.

17. Карасёв М.Н. О государственно-правовой ответственности высших должностных лиц субъектов Российской Федерации / М.Н. Карасёв // Журнал российского права. - 2000. - № 7. - С. 29-37.

18. Федулова Л.В. Конституционно-правовая ответственность высших должностных лиц субъектов Российской Федерации : автореф. дис. ... канд. юрид. наук / Л.В. Федулова. - М., 2007. - 30 с.

19. Трофимова Г.А. Основные подходы к определению оснований конституционно-правовой ответственности федеральных органов государственной власти / Г.А. Трофимова // Конституционное и муниципальное право. - 2013. - №.8. - С. 17-21.

20. Хугаева Р.Г. Конституционная ответственность высших органов государственной власти Российской Федерации : автореф. дис. ... канд. юрид. наук / Р.Г. Хугаева. - Владикавказ, 2011. - 24 с.

21. Чепус А.В. Парламентская ответственность Правительства: конституционно-правовое и сравнительное исследование : автореф. дисс. ... д-ра юрид. наук / А.В. Чепус. - Пенза, 2020. - 52 с.

22. Трофимова Г.А. Основания конституционно-правовой ответственности Президента РФ / Г.А. Трофимова // Конституционное и муниципальное право. - 2011. - № 1. - С. 3-7.

23. Добрынин Н.М. К вопросу о конституционной ответственности государства / Н.М. Добрынин // Государство и право. - 2010. - № 10. - С. 7-11.

24. Захарцев С.И. Философия и юридическая наука : монография / С.И. Захарцев, В.П. Сальников. - М. : Юрлитинформ, 2019. - 424 с.

25. Кокорин С.Н. Конституционно-правовая ответственность органов государственной власти России (в контексте национальной безопасности) / С.Н. Кокорин // Власть. - 2009. - № 2. - С. 3-7.

26. Костюков А.Н. Исчезающее народовластие / А.Н. Костюков // Конституционное и муниципальное право. - 2017. - № 8. - С. 33-38.

27. Костюков А.Н. Реализация прав человека и гражданина в конституционном праве России: год 2017 / А.Н. Костюков // Конституционное и муниципальное право. - 2017. - № 2. - С. 17-23.

28. Булатов Р.Б. Конституционное развитие российского общества: о некоторых проблемах генеральной концепции / Р.Б. Булатов, С.Ю. Андрейцо // Юридическая наука: история и современность. - 2017. - № 8. С. $59-72$

29. Боброва Н.А. Отчёт о профессорском форуме-2019. «Наука. Образование. Регионы» (Москва, 6-7 февраля 2019) / H.А. Боброва // Правоприменение. - 2019. - Т. 3, № 1. - С. 138-140. - DOI: 10.24147/2542-1514. 2019.3(1).138-140.

30. Боброва Н.А. О неконституционности критериев оценки научной деятельности вузов, установленных в декабре 2013 года / Н.А. Боброва // Конституционное и муниципальное право. - 2018. - № 6. - С. 62-66.

31. Нарутто С.В. Номенклатура научных специальностей и новая модель государственной научной аттестации / С.В. Нарутто // Правоприменение. - 2019. - Т. 3, № 1. - С. 24-32. - DOI: 10.24147/2542-1514.2019. 3(1).24-32 


\section{REFERENCES}

1. Bobrova N.A. "War of the Laws", or "On the inadmissibility of weakening guarantees of the supremacy of federal law". Zakon i pravo = Law and Legislation, 2000, no 2, pp. 28-33. (In Russ.).

2. Bobrova N.A. Duma on the Duma: diaries and memoirs of the deputy of the four convocations. To the 25 th anniversary of the Samara Governor's Duma. Samara, Samara RAS Center Publ., 2019. 195 p. (In Russ.).

3. Avakyan S.A. Russia's Constitutional Law. Vol. 2. Moscow, Norma Publ.; INFRA-M Publ., 2010. 928 p. (In Russ.).

4. Ivanov S.V. Constitutional and legal guarantees of state unity and territorial integrity of the Russian Federation. Cand. Diss. Omsk, 2018, 244 p. (In Russ.).

5. Kazannik A.I. Constitutional and legal guarantees of unity and territorial integrity of modern federative states (comparative analysis). Vestnik Omskogo Universiteta. Seriya "Pravo" = Herald of Omsk University. Series "Law", 2015, no. 4, pp. 35-46. (In Russ.).

6. Ivanov S.V. Constitutional legal support of the modern Russia's state unity and territorial integrity (socioeconomic aspect). Pravoprimenenie = Law Enforcement Review, 2019, vol. 3, no 1, pp. 44-54. DOI: 10.24147/25421514.2019.3(1).44-54 (In Russ.).

7. Malyi A.F. On the equality of rights of constituent entities of the Russian Federation and criteria for its manifestation. Konstitutsionnoe $i$ munitsipal'noe pravo = Constitutional and municipal law, 2019, no 7, pp. 51-54. (In Russ.).

8. Kostyukov A.N., Maslov K.V. The legal aspects of tax security of the state. Vestnik Omskogo Universiteta. Seriya "Pravo"= Herald of Omsk University. Series "Law", 2015, no. 4, pp. 117-121. (In Russ.).

9. Vinogradov V.A. On the constitutional torts of the legislation of the subjects of the Russian Federation, in: Avakyan S.A. (ed.). Constitutional law of subjects of Russian Federation. Moscow, MSU Publ, 1999. Pp. 33-37. (In Russ.).

10. Lebedev V.A. The theoretical basis of the constitutional and legal responsibility of the subjects of the Russian Federation. Vestnik Chelyabinskogo gosudarstvennogo universiteta. Seriya: Pravo = Bulletin of Chelyabinsk State University. Series: Law, 2001, no. 1, pp. 45-51. (In Russ.).

11. Narutto S.V. Problems of legal responsibility of the subject of the Federation. Pravovedenie, 1998, no. 4, pp. 17-22. (In Russ.).

12. Agapov A.S. Constitutional and legal responsibility in federal relations. Cand. Diss. Thesis. Moscow, 2008. 24 p. (In Russ.).

13. Bartsits I.N. Federal Responsibility. Constitutional and legal aspects. Moscow, REA Publ., 1999. 197 p. (In Russ.).

14. Zametina T.V. Constitutional and legal frameworks for federal responsibility. Leningradskii yuridicheskii zhurnal = Leningrad Legal Journal, 2012, no. 2, pp. 4-9. (In Russ.).

15. Bezrukov A.V. Modernization of measures of constitutional responsibility of State authorities of the subjects of the Russian Federation in the context of federal transformations. Gosudarstvennaya vlast' i mestnoe samoupravlenie = State power and local self-government, 2010, no. 5, pp. 55-59. (In Russ.).

16. Kondrashov A.A. Constitutional and legal responsibility of the subjects of the federation: theory and legislative regulation in the Russian Federation. Krasnoyarsk, Siberian Law Institute of MIA of Russia Publ., 1999.111 p. (In Russ.).

17. Karasev M.N. On the state-legal responsibility of the highest officials of the subjects of the Russian Federation. Zhurnal rossiiskogo prava = Journal of Russian Law, 2000, no. 7, pp. 29-37. (In Russ.).

18. Fedulova L.V. Constitutional and legal responsibility of the highest officials of the subjects of the Russian Federation, Cand. Diss.Thesis. Moscow, 2007. 30 p. (In Russ.).

19. Trofimova G.A. The main approaches to determining the grounds of constitutional and legal responsibility of the federal authorities. Konstitutsionnoe i munitsipal'noe pravo = Constitutional and municipal law, 2013, no. 8, pp. 17-21. (In Russ.).

20. Hugaeva R.G. Constitutional Responsibility of the Highest Authorities of the Russian Federation. Cand. Diss.Thesis. Vladikavkaz, 2011. 24 p. (In Russ.). 
21. Chebus A.V. Parliamentary Responsibility of the Government: constitutional and legal and comparative research. Doct. Diss. Thesis. Penza, 2020. 52 p. (In Russ.).

22. Trofimova G.A. The foundations of the constitutional and legal responsibility of the President of the Russian Federation. Konstitutsionnoe i munitsipal'noe pravo = Constitutional and municipal law, 2011, no. 1, pp. 3-7. (In Russ.).

23. Dobrynin N.M. To the question of the constitutional responsibility of the state. Gosudarstvo $i$ pravo $=$ State and Law, 2010, no. 10, pp. 7-11. (In Russ.).

24. Zakhartsev S.I., Salnikov V.P. Philosophy and Legal Science. Moscow: Jurlitinform Publ., 2019. 424 p. (In Russ.).

25. Kokorin S.N. Constitutional and legal responsibility of the Russian state authorities (in the context of national security Vlast' $=$ The Authority, 2009, no. 2, pp. 3-7. (In Russ.).

26. Kostyukov A.N. Vanishing democracy. Konstitutsionnoe i munitsipal'noe pravo = Constitutional and municipal law, 2017, no. 8, pp. 33-38. (In Russ.).

27. Kostyukov A.N. Implementation of human rights and citizens in Russia's constitutional law: year 2017. Konstitutsionnoe i munitsipal'noe pravo = Constitutional and municipal law, 2017, no 2, pp. 17-23. (In Russ.).

28. Bulatov R.B., Andreytso S.Yu. The Constitutional Development of Russian Society: About Some Problems of the General Concept. Yuridicheskaya nauka: istoriya i sovremennost', 2017, no. 8, pp. 59-72. (In Russ.).

29. Bobrova N.A. 2019 Professorial Forum. "Science. Education. Regions" (Moscow, February 6-7, 2019). Pravoprimenenie = Law Enforcement Review, 2019, vol. 3, no 1, pp.138-140. DOI: 10.24147/2542-1514.2019.3(1). 138-140 (In Russ.).

30. Bobrova N.A. On the unconstitutionality of the criteria for assessing the scientific activity of universities, established in December 2013. Konstitutsionnoe i munitsipal'noe pravo = Constitutional and municipal law, 2018, no. 6, pp. 62-66. (In Russ.).

31. Narutto S.V. The Nomenclature of scientific specialties and the new model of award of academic degrees: Russian Experience. Pravoprimenenie = Law Enforcement Review. 2019, vol. 3, no. 1, pp. 24-32. DOI: 10.24147/25421514.2019.3(1).24-32 (In Russ.).

\section{ИНФОРМАЦИЯ ОБ АВТОРАХ}

Блохина Наталья Алексеевна - кандидат юридических наук, доцент, доцент кафедры конституционного и административного права

Тольяттинский государственный университет 445020, Россия, г. Тольятти, ул. Белорусская, 14

E-mail: tolrec@mail.ru

SPIN-код РИНЦ: 1925-0161; AuthorID: 634491

Власова Мария Алексеевна - аспирант кафедры конституционного и административного права Тольяттинский государственный университет 445020, Россия, г. Тольятти, ул. Белорусская, 14 E-mail: MAZ80@yandex.ru

\section{БИБЛИОГРАФИЧЕСКОЕ ОПИСАНИЕ СТАТЬИ}

Блохина Н.А. Ответственность президента и прокуратуры за целостность и безопасность государства / Н.А. Блохина, М.А. Власова // Правоприменение. - 2021. - Т. 5, № 2. - С. 86-98. - DOI: 10.52468/2542-1514.2021.5(2).86-98.

\section{INFORMATION ABOUT AUTHORS}

Natalia A. Blokhina - PhD in Law, Associate Professor; Associate Professor, Department of Constitutional and Administrative Law Togliatti State University 14, Belorusskaya ul., Togliatti, 445020, Russia E-mail: tolrec@mail.ru RSCI SPIN-code: 1925-0161; AuthorID: 634491

Maria A. Vlasova - PhD student, Department of Constitutional and Administrative Law

Togliatti State University

14, Belorusskaya ul., Togliatti, 445020, Russia

E-mail: MAZ80@yandex.ru

\section{BIBLIOGRAPHIC DESCRIPTION}

Blokhina N.A., Vlasova M.A. Responsibility of the president and the prosecutor's office for the integrity and security of the state. Pravoprimenenie = Law Enforcement Review, 2021, vol. 5, no. 2, pp. 86-98. DOI: 10.52468/2542-1514.2021.5(2).86-98. (In Russ.). 